\title{
МЕДИЧНА ЕТИКА І ДЕОНТОЛОГІЯ: РЕАЛІЇ І ПЕРСПЕКТИВИ В РОБОТІ ЛІКАРЯ
}

\author{
С. С. Левенець
}

ДВНЗ “Тернопільський державний медичний університет імені І. Я. Горбачевського МОЗ Украӥни”

\section{MEDICAL ETHICS AND DEONTOLOGY: REALITIES AND PROSPECTS IN THE WORK OF A DOCTOR}

\author{
S. S. Levenets \\ SHEI "Ternopil State Medical University by I. Ya. Horbachevsky of MPH of Ukraine”
}

\begin{abstract}
Висвітлені поняття медичної етики і деонтології, історична довідка їхнього формування і розвитку у світі та в Україні. Показані основні положення Етичного кодексу українського лікаря.

There are adduced the concepts of medical ethics and deontology historical background of their formation and development in the world and in Ukraine. The main provisions of the Code of Ethics of the Ukrainian doctor are shown.
\end{abstract}

Вступ. 3 стародавніх часів і до сьогодні професія лікаря є однією з найбільш гуманних. Це лежить в основі ставлення суспільства до представників цієї професії. Кожна людина впродовж життя хоча б раз мала необхідність звернутися до лікаря і має право сподіватися на гідне, шанобливе ставлення до себе. Проблемами стосунків між лікарями і пацієнтами займається така наука, як лікарська етика і деонтологія $[1,4]$.

Основна частина. Етика - це вчення про мораль, iї походження і розвиток, правила і норми поведінки людей, їх обов'язки під час стосунків одного з іншим, з суспільством, ставлення до праці, держави. Етика - це філософське вчення про моральність як одну 3 форм ідеології, про ії сутність, закони історичного розвитку, роль у суспільстві. Це система норм моральної поведінки людей, їх обов'язків щодо суспільства, батьківщини. Медична етика - це вчення про мораль медпрацівників, їх поведінку, взаємозв'язки 3 хворими, з колегами, із суспільством [4, 5].

Засновником лікарської етики заслужено вважається Гіппократ, який на підставі багатовікового досвіду медицини систематизував правила медичної етики, що існували на той час. Кодекс моральних норм, обов'язкових для тих, хто вибрав своєю професією лікування людей, містився в його працях "Клятва", "Про лікаря", "Про благопристойну поведінку". Гіппократу належить відомий вислів: "Медицина $\epsilon$ найблагородніше зі всіх мистецтв".

Основними принципами медичної етики є такі [7]: 1. Гуманне ставлення до хворого.
2. Не брати участі в діях проти здоров'я хворого.

3. Надання допомоги всім, хто ії потребує, незалежно від расової, політичної і релігійної приналежності.

4. Солідарність усіх лікарів у повазі гідності людей, їх боротьбі за мир.

5. Збереження лікарської таємниці.

6. Участь в охороні життя людей від тих чи інших ексцесів, що загрожують їм (наприклад, від забруднення зовнішнього середовища).

7. Недопущення експериментів над людьми.

8. Утримання від вчинків, які можуть принизити гідність професії лікаря.

З позицій соціального регулювання медичної діяльності лікарська (медична) етика - це різновид професійної етики, що включає сукупність моральноетичних правил i принципів надання медичної допомоги. Медична етика слугує своєрідною теоретичною основою, обгрунтуванням моральноетичної поведінки медичних працівників $[4,5,7]$. Медична етика вивчає і визначає вирішення різних проблем міжособистісних взаємовідносин 3 трьох основних напрямів:

- медичний працівник - хворий;

- медичний працівник - здорова людина (родичі);

- медичний працівник - медичний працівник.

Біоетика-це важливе поняття філософського знання [2]. Формування і розвиток біоетики пов'язані 3 процесами трансформації традиційної етики взагалі, медичної і біологічної етики зокрема. Цей процес

(C) С. С. Левенець 
зумовлений, перш за все, різко підсиленою увагою до прав людини (в медицині-це права пацієнта, досліджуваного і т. д.) і створенням нових медичних технологій, які призводять до багатьох проблем, що потребують вирішення, як з точки зору права, так i моралі [2].

Складовою частиною медичної етики є деонтологія (від грецьк. deon, deontos - належне; належне + $\operatorname{logos}$ - вчення). Медична деонтологія - це сукупність етичних норм і принципів поведінки медичного працівника при виконанні своїх професійних обов'язків. Деонтологія - це практичне застосування медичної етики. Вона займається проблемами належної поведінки медика при безпосередньому виконанні своїх професійних обов'язків. Термін “деонтологія” ввів в ужиток англійський філософ І. Бентам у своїй книзі “Деонтологія, або наука про мораль”, де деонтологія розумілась як особиста поведінка індивіда і дещо протиставлялася етиці, яка в загальновизнаному тоді розумінні була соціальним інститутом, що вивчав правильну поведінку людей у суспільстві. Порушення правил деонтології може призвести до виникнення такої патології, як ятрогенія - психогенний розлад внаслідок неправильних, необережних висловлювань або дій медичного працівника.

Тому важливим принципом є дотримування основного деонтологічного правила - не зашкодити при діагностиці або лікуванні.

Проблеми деонтології в медицині вперше були висвітлені в роботах відомого хірурга-онколога М. М. Петрова, що розкрив зміст деонтології і показав шляхи іiі розвитку. Пріоритет серед лікарів у питаннях лікарської етики належить видатному клініцистові С. П. Боткіну, який вперше в практиці російської медицини обгрунтував необхідність створення етичного кодексу російського лікаря. Свій вклад у розвиток деонтології та етики внесли визначні вчені сучасності Н. П. Сокольський, О. Т. Михайленко, Г. К. Степанівська та інші [4].

Нині з огляду на попередні і сучасні напрацювання у сфері медичної етики і деонтології є неприпустимим швидке ухвалення нових правових актів без врахувань питань медичної етики і деонтології. Поверхневий, недостатньо відпрацьований, створений без урахування етичних і деонтологічних передумов правовий акт, без сумніву, більш шкідливий, ніж корисний. Адже велика кількість положень сучасної медичної етики сформована на основі стародавніх постулатів, які і тепер не втратили актуальності. Широке розповсюдження у медицині має вислів: “Salus aergoti suprema lex" (“Благо хворого - вищий закон”). Цей вислів, без сумніву, містить одну з головних складових, основний принцип медичної діяльності всього етичного напряму в медицині. Відповідно до нього головним правилом, “вищим законом” для лікаря при виконанні ним професійних обов’ язків $є$ і повинен бути пріоритет хворого - його благо, його здоров'я. На сьогодні цей принцип повинен бути затребуваний у процесі медичної законотворчості: правові акти в системі охорони здоров'я мають містити орієнтацію на хворого, на його права та дотримання його законних інтересів.

Впродовж тривалого часу етичні положення існували або у вигляді окремих положень і висловів, або у вигляді перекладених і адаптованих праць стародавніх мислителів: Гіппократа, Галена та інших. На сьогодні лікарі орієнтуються на документи, прийняті в епоху світових інтеграційних процесів у другій половині XX - на початку XXI ст. До них відноситься Женевська декларація Всесвітньої медичної асоціації, прийнята в 1948 р., із змінами і доповненнями 1968 і 1983 рр., оріснтована на майбутніх лікарів випускників медичних вузів. Деклараціяє своєрідною клятвою лікаря, містить ряд положень щодо правового регулювання медичної діяльності: “Я виконуватиму свій професійний обов’ язок чесно і з гідністю”, або “Я не дозволю з міркувань релігії, національності, раси, політичних переконань або соціального походження перешкодити виконанню мого обов' язку і постати між мною і моїм пацієнтом". В обов' язок лікаря входить надання пацієнту допомоги, незалежно від соціальних та інших ознак. У разі ненадання медичної допомоги лікарем йдеться про юридичну кримінальну відповідальність. Міжнародний кодекс медичної етики, прийнятий Генеральною асамблеєю Всесвітньої медичної асоціації у 1949 р., із змінами і доповненнями 1968, 1983, 1994 рр. - документ, що визначає критерії неетичності в поведінці медичного працівника, а також - обов'язку лікаря у відношенні до хворого і один до одного. Даний кодекс містить положення, при якому завжди, коли обстеження або лікування вимагають знань, що перевищують здібності лікаря, він повинен запросити інших лікарів, що мають відповідну кваліфікацію. Лікарська таємниця, як поняття, що знайшло своє віддзеркалення у правових документах з охорони здоров'я, також представлена в Міжнародному кодексі медичної етики. Йдеться про положення Кодексу: “Лікар повинен зберігати абсолютну конфіденційність у всьому, що стосується пацієнтів, які йому довіряються". Дане положення містить зв'язок морально-етичних і правових норм у регулюванні медичної діяльності [8]. 
До основних акцій Всесвітньої медичної асоціації також відносяться Хельсінська декларація прав людини (1964), Хельсінсько-Токійська декларація (1975), Міжнародна декларація про права людини (1983).

Пріоритети професійної незалежності лікаря викладені в Декларації про незалежність і професійну свободу лікаря, прийнятій Всесвітньою медичною асоціацією у 1986 р.: "Професійна свобода лікаря передбачає свободу від стороннього втручання у лікувальний процес. Завжди і всюди слід охороняти i захищати незалежність професійних медичних й етичних рішень лікаря”. Так у Декларації проголошується незалежність лікаря при виконанні своїх професійних обов'язків. Це не стосується питань адміністративної підлеглості. Це стосується свободи ухвалення рішень щодо користі хворого - тактики і схеми лікування, застосування тих або інших методів, іншими словами, всього, що спрямоване на благо хворого.

Період демократичних перетворень в Україні характеризується прийняттям низки документів, присвячених морально-етичному і деонтологічному регулюванню медицини: "Присяга лікаря" - стаття 76 Основ законодавства України про охорону здоров’я та Клятва лікаря, що затверджена наказом Президента України 15 червня 1992 року [3, 8]. Цю клятву повинні давати усі випускники вищих навчальних закладів України. Отримуючи звання лікаря, випускник присягається "усі знання, сили та вміння віддавати справі охорони і поліпшення здоров’я людини, лікуванню і запобіганню захворюванням, надавати медичну допомогу всім, хто їі потребує, зберігати лікарську таємницю, додержуватись правил професійної етики”. Цей акт відповідає нормам медичної етики і деонтологічним принципам, враховує міжнародний досвід та етичні норми клятви Гіппократа. Обов' язки, закріплені у присязі, є моральними вимогами до професії.

В Україні на Всеукраїнському з’ізді лікарських організацій та X 3’їді Всеукраїнського лікарського товариства (ВУЛТ) в м. Свпаторії 27 вересня 2009 року прийнято та підписано Етичний кодекс українського лікаря [8]. Головними фундаментальними цінностями, названими в Кодексі, є життя та здоров'я людини. Діяльність лікаря спрямована на їх збереження від моменту зачаття та вимагає від нього гуманного ставлення до людини, поваги до іії особистості, співчуття та співучасті, доброзичливості, благодійності та милосердя, терплячості, взаємодовіри, порядності та справедливості. Лікар повинен пам'ятати, що головний суддя на його професійному шляху - це, насамперед, совість. Ці моральні засади систематизовані в Етичному кодексі лікаря України з урахуванням положень Міжнародного кодексу лікарської етики, Гельсінської декларації, Загальної декларації про геном і права людини й Конвенції про захист прав та гідності людини з огляду на застосування досягнень біології та медицини. Цей Кодекс призначений для застосування у професійній діяльності лікарів і науковців, сфера професійної діяльності яких охоплює пренатальне та постнатальне життя та здоров'я людини, іiі народження та смерть.

Структура Кодексу має такий вигляд:

РОЗДІЛ 1. ДІЯ КОДЕКСУ

Відмічено, що положення Кодексу необхідно виконувати лікарям, адміністративному персоналу і науковцям, які мають безпосереднє відношення до лікувально-профілактичної та наукової діяльності у галузі охорони здоров'я.

РОЗДІЛ 2. ЛІКАР ТА СУСПІЛЬСТВО

Вказано, що головна мета професійної діяльності лікаря (практика і вченого) - збереження та захист життя й здоров' я людини в пренатальному і постнатальному періоді, профілактика захворювань і відновлення здоров'я, а також зменшення страждань при невиліковних хворобах, при народженні і настанні смерті. Лікар виконує свої обов'язки з повагою до життя, гідності і особистості кожного пацієнта на основі морально-етичних принципів суспільства, виходячи з Клятви лікаря України та цього Кодексу

РОЗДІЛ З. ЛІКАР і ПАЦІЕНТ

- Лікар і пацієнт, де висвітлюються права пацієнтів, регламентується реалізація цих прав через обов'язки лікарів.

- Лікар і права членів сім’ї, законних представників.

РОЗДІЛ 4. КОЛЕГІАЛЬНІСТЬ ЛІКАРІВ

Окреслені взаємодія і відносини з колегами та іншими працівниками системи охорони здоров'я: лікар зобов'язаний охороняти честь і шляхетні традиції медичного співтовариства, з повагою і доброзичливістю ставитися до колег. Протягом усього життя лікар зобов’ язаний зберігати повагу і почуття подяки до тих, хто навчав його мистецтва лікування тощо.

РОЗДІЛ 5. НАУКОВІ ДОСЛІДЖЕННЯ ЗА УЧАСТЮ ПАЦІСНТА

Детально описані умови наукових досліджень 3 участю пацієнтів, що проводяться лікарем. Лікар може поєднувати дослідження з наданням медичної допомоги лише у випадках, коли дослідження обгрунтоване профілактичною, діагностичною або терапевтичною метою.

РОЗДІЛ 6. НОВІТНІ МЕДИЧНІ ТЕХНОЛОГІЇ

Описані вимоги до дій лікаря при застосуванні новітніх медичних технологій (трансплантація людсь- 
ких органів і тканин, втручання в геном людини, у репродуктивну функцію тощо) визначаються етикоправовими і законодавчо-нормативними актами України, рекомендаціями та вимогами Всесвітньої організації охорони здоров'я, Біоетичного комітету ЮНЕСКО та Комісії з питань біоетики.

\section{РОЗДІЛ 7. ІНФОРМАЦІЯ}

Лікар зобов'язаний постійно підвищувати свою кваліфікацію, бути поінформованим стосовно найновіших досягнень у сфері професійної діяльності. Він повинен активно протистояти будь-якій недостовірній інформації у наукових виданнях та засобах масової інформаціі.

\section{РОЗДІЛ 8. ПОВАГА ДО ПРОФЕСІЇ ЛІКАРЯ}

Принцип поваги до своєї професії повинен бути витриманим у всіх сферах діяльності лікаря: професійній, громадській, публіцистичній тощо. Кожний лікар повинен утримуватися від будь-яких дій чи висловлювань, які підривають повагу до медичної спеціальності. Своєю діяльністю він повинен сприяти збереженню та підвищенню престижності професії, до якої належить, а також дієвості цього Кодексу.

\section{Література}

1. Макеєва Л. А. Теоретичні проблеми лікарської етики і медичної деонтології в умовах сучасної НТР : автореф. дис. к.ф.н. / Л. А. Макеєва. - Л., 1985.-21 с.

2. Основи законодавства України про охорону здоров'я/// Відомості Верховної Ради (ВВР) : Стаття 76. Присяга лікаря України. - 1993.-№4.-С. 19.

3. Петровский Б. В. Вопросы врачебной этики и современность / Б. В. Петровский // Вестн. Рос. АМН. - 1996. № 11. - С. 3-5.

4. Петровский Б. В. Деонтология в медицине / Б. В. Пет-
На думку авторів, цей Кодекс повинен бути затверджений Указом Президента України, на зразок Клятви лікаря України, i, відповідно, має стати підзаконним нормативно-правовим актом.

Висновки. Дотримання норм і принципів, прописаних у Кодексі, сприятиме налагодженню конструктивного діалогу між лікарем та пацієнтом. Прийняття Кодексу дає можливість зрозуміти, що професія лікаря залишається тим моральним орієнтиром, який сприятиме підвищенню довіри суспільства до лікаря. Якою б актуальною не була сьогодні проблема прискореного розвитку медичної науки і впровадження їі досягнень у практику охорони здоров'я, розширення й укріплення матеріальної бази лікувальних закладів, оснащення їх новітньою технікою і апаратурою, і надалі продовжує мати важливе значення питання про моральні якості медичного працівника, його ставлення до свого фахового обов'язку й професійної підготовки. Особистість медичного персоналу, їх моральний вигляд і персональна підготовкаце у кінцевому результаті й визначає значний успіх охорони здоров’я в державному масштабі.

ровский. - М. : Медицина, 1988.

5. Седова Н. Конфликты в этической экспертизе / Н. Седова // Международный журнал медицинской практики. 2006. - №3. - С. 13-15.

6. Углов Б. Г. О врачебном долге / Б. Г. Углов. - К. : Здоров'я, 1987.- 104 с.

7. Про Клятву лікаря : Указ Президента України № 349 від 15 червня 1992 року.

8. www.nmu.edu.ua/files/etichnij_kodeks.pdf 